\title{
INFLUENCE OF SURFACTANTS ON COPPER-CNTS ELECTRODEPOSITION
}

\author{
Iryna Roslyk ${ }^{1, \otimes}$, Ganna Stovpchenko ${ }^{2}$, Galyna Galchenko ${ }^{1}$
}

https://doi.org/10.23939/chcht15.01.125

\begin{abstract}
Influence of different types of surfactants on electrodeposition of copper- and carbon-bearing (graphite, carbon nanotubes (CNTs)) composite powder has been experimentally investigated. The size of powder particles decreased, and corrosion resistance increased when surfactants were added. Addition of cationic surfactant $\mathrm{CTAB}$ to the electrolyte with simultaneous ultrasonic treatment for CNTs dispersion gives maximum effect.
\end{abstract}

Keywords: surfactants, carbon nanotubes (CNTs), copper composite powder, electrodeposition, ultrasonic treatment, corrosion resistance.

\section{Introduction}

Composite copper-graphite powders are widely used for sintering of various materials for electrical applications.

Chemical [1-2] and electrochemical deposition [34] are the most common methods for such composite powders manufacturing. Chemical deposition has several disadvantages, like complex pre-treatment of graphite powder and unstable composition of electrolyte. The advantage of electrochemical method is high rate of metal deposition, stability of the electrolyte and relatively low costs. In addition, the properties of composite powders can be controlled at deposition by varying the electrolyte chemistry, electrical regimes, etc. In other cases, powders size could be changed at further processing (drying, grinding, scattering) only.

Nowadays, great prospects in material science of composites are associated with the use of nanosized fillers [5], among which the carbon nanotubes (CNTs) are of great interest, because of unique set of properties: high strength, elasticity modulus, as well as electrical and thermal conductivity (5 times higher than copper). Such characteristics make prospects for development the coppergraphite composites for electrical applications: high-voltage bursting and high-current sliding contacts [6-8].

\footnotetext{
${ }^{1}$ National Metallurgical Academy of Ukraine,

4, Gagarina Ave., 49600 Dnipro, Ukraine

${ }^{2}$ Paton Electric Welding Institute of NAS of Ukraine,

11, K.Malevych St., 03150 Kyiv, Ukraine

roslyk67@gmail.com

(c) Roslyk I., Stovpchenko G., Galchenko G., 2021
}

The uniform distribution of various phases in a composite material volume has key importance to guarantee its high and stable properties. On the contrary, carbon nanotubes tend to gather in balls, where hundred and thousand pieces of CNT entangle under the action of the Van der Waals forces. Thus, their separation before input into a matrix is very important making development of methods capable to provide CNTs disconnection a topical issue. The dispersing of CNT aggregates by ultrasonic waves [9-13] is used most widely. Ultrasonic treatment of electrolytes with the addition of cationic and anionic surfactants allows forming stable suspensions of microparticles at deposition, because all surfactants help decrease the surface tension and free energy at the interface between the carbon component and the aqueous electrolyte solution.

Several papers [14-18] show the results of copperCNT composite coatings deposited from electrolytes with various additives. Thus, Schneider et al. [14] obtained a multilayered material, and studied the processes of copper electrochemical precipitation from an aqueous electrolyte on a layer of multi-wall carbon nanotubes (MWCNTs). To improve the wettability of the hydrophobic surface of the tubes, $0.001 \mathrm{M}$ sodium dodecyl sulfate (SDS) was added to the electrolyte. This contributed to the deposition of a homogeneous layer of copper on the CNT surface. Anionic surfactant SDS in concentration of $300 \mathrm{mg} / \mathrm{l}$ was added to the electrolyte to improve the wettability of CNT [17]. This led to incorporated CNT content in the copper coating as high as $2.84 \mathrm{wt} \%$. Arai et al. $[15,16]$ in order to achieve homogeneous dispersion of CNT in the electrolyte, added polyacrylic acid PA-5000 in the amount of $100 \mathrm{ppm}$ to the base bath under stirring. In order to increase the CNT content in thin films, a suspension of $5 \mathrm{wt} \%$ solution of diallyldimethylammonium chloride (PDDA) was prepared [18] resulting in the increase of CNTs content in copper-CNT films by 4-6 times.

The effect of two surfactants (above mentioned SDS and hexadecyltrimethylammonium bromide $\mathrm{CTAB}$ ) on the electrodeposition of Ni-CNTs composite coating was studied by Guo and co-workers [19]. The results showed that SDS addition in the bath slightly decreased, but CTAB increased the content of co- 
deposited CNTs in the coatings. In addition, when applying $\mathrm{CTAB}$ the nickel coating grains size was smaller. Effect of hexadecyltrimethylammonium bromide (CTAB) and polyoxyethylene octyl phenyl on deposition process of a coating containing copper and graphite powder has been investigated in [4]. It is shown that addition of surfactant to electrolyte helps to stabilize and evenly distribute graphite in the electrolyte. Among the studied surfactants, the highest quality copper-graphite deposits were obtained from electrolytes containing CTAB. The CTAB concentration of $150 \mathrm{mg} / \mathrm{dm}^{3}$ was recommended.

Electric parameters and other conditions of copperCNT composite powder co-deposition are also important $[20,21]$. Thus, Zheng et al. [20] reported that $\mathrm{Cu}-\mathrm{CNT}$ powder was electrodeposited from the sulphate bath electrolyte with $90 \mathrm{~g} / \mathrm{l} \mathrm{CuSO}_{4} \cdot 5 \mathrm{H}_{2} \mathrm{O}$ and $20 \mathrm{ml} / 1$ of $98 \%$ $\mathrm{H}_{2} \mathrm{SO}_{4}$ with the current density of $300 \mathrm{~mA} / \mathrm{cm}^{2} .100 \mathrm{mg} / 1$ of carbon nanotubes were added to the electrolyte. CNTs were pretreated by $\mathrm{HNO}_{3}$ to form $-\mathrm{COOH}$ functional group on their surface. It is shown that when adding CNT to an electrolyte, the size of copper powder particles decreases to 0.6 microns. There are a few papers devoted to manufacturing of the copper-CNTs composite powder. Arai et al. [21] obtained $\mathrm{Cu}-\mathrm{CNTs}$ composite powder with CNT content of $2 \mathrm{~g} / \mathrm{dm}^{3}$, which was produced by electrodeposition with addition of polyacrylic acid (PA5000) as a dispersant to the electrolyte in the amount of $2 \cdot 10^{-5} \mathrm{M}$. Adding polyacrylic acid to the base electrolyte has resulted in more uniform distribution of CNTs in the deposited powder.

The publications review has shown that surfactants (SDS, CTAB, polyacrylic acid) addition facilitates codeposition of copper and carbon particles; that is why they were chosen for the further investigation.

This research focuses on co-deposition process of copper and carbon (graphite, CNTs) for composite powders manufacturing as well as on estimation of different surfactant effect on morphology and size of deposited particles and their corrosion resistance as an indirect factor of particle stability.

\section{Experimental}

The electrolyte for co-deposition of composite powder consists of copper sulfate $(40 \mathrm{~g} / \mathrm{l})$ and sulfuric acid $(130 \mathrm{~g} / \mathrm{l})$ water solution. Direct current of $10 \mathrm{~A} / \mathrm{dm}^{2}$ density was used for deposition during $0.5 \mathrm{~h}$. The bath temperature was kept around $303 \mathrm{~K}$. Pure copper plates (area of each one was about $37 \mathrm{~cm}^{2}$ ) were set as a soluble anode and cathode. The volume of the plating bath was
$500 \mathrm{~cm}^{3}$. The electrolyte was mixed by magnetic stirrer with the frequency of $850 \mathrm{~min}^{-1}$. The deposited powders were collected, washed by distilled water, stabilized to prevent oxidation and finally dried at $313 \mathrm{~K}$.

In this research the anionic surfactant sodium lauryl sulfate (sodium dodecyl sulfate) $\mathrm{NaCl}_{2} \mathrm{H}_{25} \mathrm{SO}_{4}$ (SDS) with the concentration of $0.5-1 \mathrm{~g} / 1$, cationic surfactant cetyltrimethylammonium bromide $\mathrm{C}_{19} \mathrm{H}_{42} \mathrm{BrN}$ (CTAB) with the concentration of $0.15-0.3 \mathrm{~g} / \mathrm{l}$, and polyacrylic acid PA4000 with the concentration of $0.025-0.05 \mathrm{~g} / \mathrm{l}$ were under study. 3D molecular structures of selected surfactants are presented in Fig. 1. Hyperchem (Hypercube Inc., Gainesville, FL, USA) software simulating molecular structure, which helps to draw, edit and manipulate molecules shape to calculate bonds energies and to optimize molecular geometries on the base of molecular mechanics was used.

It is known that molecules with best surfactant properties are amphifilic ones. They often contain various hydrophobic tails and several hydrophilic heads and can dissociate in an electrolyte forming a positively charged organic cation and anion. The hydrophobic group is typically a large hydrocarbon radical consisting of 10-18 carbon atoms, usually of a linear structure [22].

Two sorts of carbonaceous materials were added to the electrolyte for co-deposition: powder of pencil grade graphite (GK-3) and multi-walled carbon nanotubes. The chemical composition of the graphite powder was as follows: carbon - at least $94 \%$, ash - no more than $5 \%$, volatile ones - no more than $1 \%$, humidity - no more than $1 \%$. The average particle size was $40 \mu \mathrm{m}$. Multiwalled CNTs (outer diameter 8-28 nm, length $0.5-10 \mu \mathrm{m}$ ) were produced via chemical vapor deposition method (CVD), the essence of which is a propylene decomposition at $923 \mathrm{~K}$ in the presence of $\mathrm{Al}_{2} \mathrm{O}_{3}-\mathrm{Fe}_{2} \mathrm{O}_{3}$ $\mathrm{MoO}_{3}$ catalyst. The CNTs concentration in the plating bath was $0.18 \mathrm{~g} / \mathrm{l}$, chosen according to literature recommendations.

The appearance and morphology of the electrodeposited copper powder were observed by scanning electron microscopy (SEM) (Tescan Mira 3 LMU). Energy dispersive X-ray spectrometry (EDS) ("X-max 80" Oxford Instruments, England) was used for local chemical analysis of produced powders.

Electrochemical investigations were carried out using potentiostat PI-50-1. The potentials were recorded relative to the chloride electrode and measured every 60 seconds. Then the data was transferred to the normal hydrogen scale. The area of sample exposed to the electrolyte was about $1 \mathrm{~cm}^{2}$. The tests were performed in $3 \mathrm{M} \mathrm{NaCl}$ solution at $293 \mathrm{~K}$. 


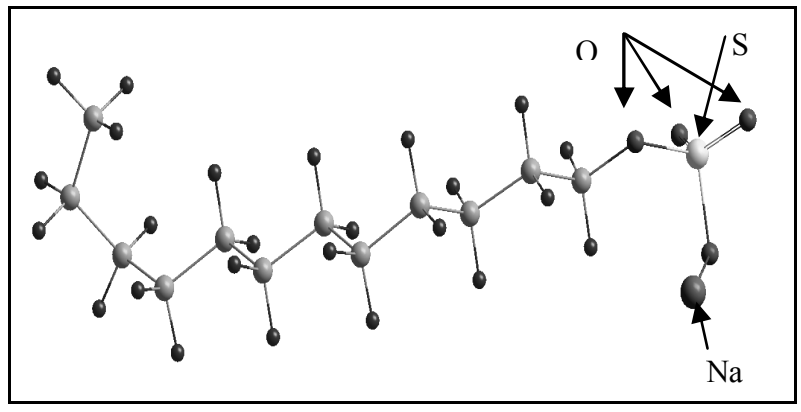

a)

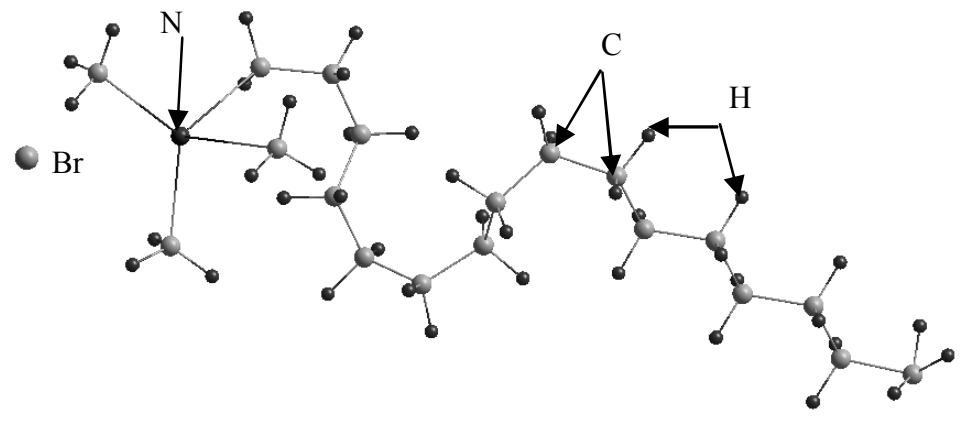

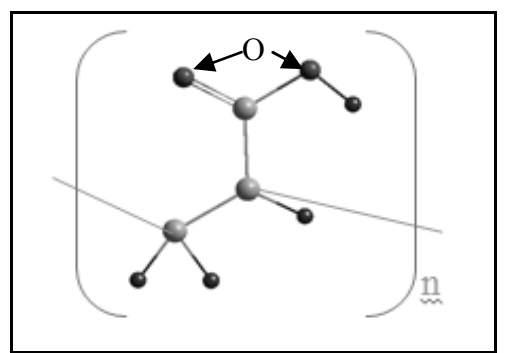

c)

Fig. 1. 3D molecular structure of surfactants SDS (a); CTAB (b) and PA (c)

b)

\section{Results and Discussion}

First series of experiments was carried out to detect the influence of surfactant on the electrodeposition process of copper-carbon (graphite, CNTs) composite powder, the size and morphology of forming particles (Table).

It was shown that during electrodeposition without any surfactant in the electrolyte, the copper ions discharge on the cathode, but large graphite particles found in deposite were not bonded with copper particles (Fig. 2a). The addition of all types of surfactants supports codeposition of copper and graphite. It is clearly shown in Fig. $2 b$ that powder received in solution with surfactant CTAB consists of copper deposited on graphite particles. Addition of surfactant CTAB to the electrolyte reduces the size of copper particles more than other surfactants (more than twice). Electrodeposition with surfactant PA4000 leads to the formation of dendrites with rounded peaks (Fig. 3). Deposits of such form could be further grinded to obtain ultra-fine powders with good flowability, which is important for powder that will be formed, for example, by injection molding.

Electrodeposition with surfactant SDS leads to formation of multifaceted powders with branched dendrites (Fig. 4).

The first series of experiments with graphite as carbon component have demonstrated that addition of the surfactant CTAB helps to form the most dispersed composite powders, in which copper is deposited on the surface of graphite particles. Powders produced in the solutions with other surfactants have the same structure as well, but consists of bigger size particles (conglomerates up to $160 \mu \mathrm{m}$ ). Therefore, for further experiments with CNT the surfactant CTAB in the amount of $0.3 \mathrm{~g} / 1$ was used only.

Table

Concentration of electrolyte additions in the experiments

\begin{tabular}{|c|c|c|}
\hline \multirow{2}{*}{ \# Sample } & \multicolumn{2}{|c|}{ Concentration of electrolyte additions } \\
\cline { 2 - 3 } & Carbon material, $\mathrm{g} / \mathrm{S}$ & Surfactant, $\mathrm{g} / \mathrm{l}$ \\
\hline 1 & graphite, 0.6 & - \\
\hline 2 & graphite, 0.6 & PA, 0.025 \\
\hline 3 & graphite, 0.6 & PA, 0.05 \\
\hline 4 & graphite, 0.6 & SDS, 0.5 \\
\hline 5 & graphite, 0.6 & SDS, 1.0 \\
\hline 6 & graphite, 0.6 & CTAB, 0.15 \\
\hline 7 & graphite, 0.6 & CTAB, 0.3 \\
\hline 8 & CNT, 0.18 & CTAB, 0.3 \\
\hline
\end{tabular}




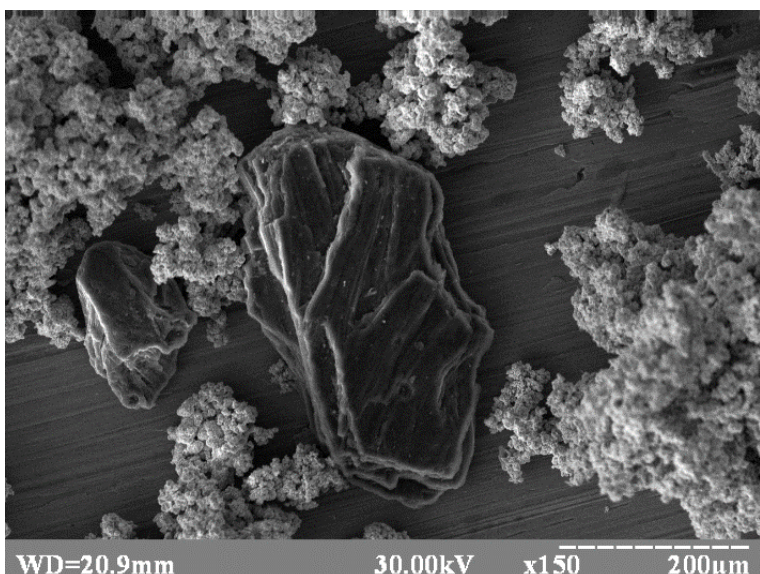

a)

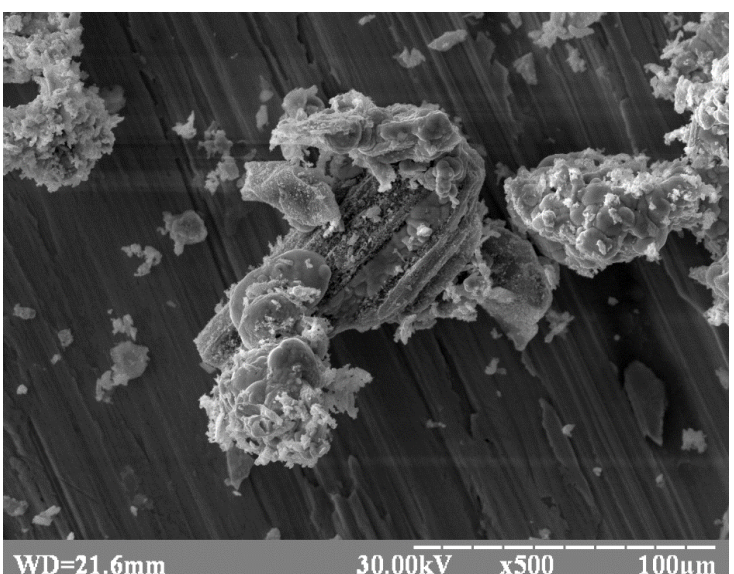

b)

Fig. 2. Morphology of the electrodeposited powder "copper-graphite" without surfactant (a) and with $0.3 \mathrm{~g} / \mathrm{l}$ of surfactant CTAB (b)
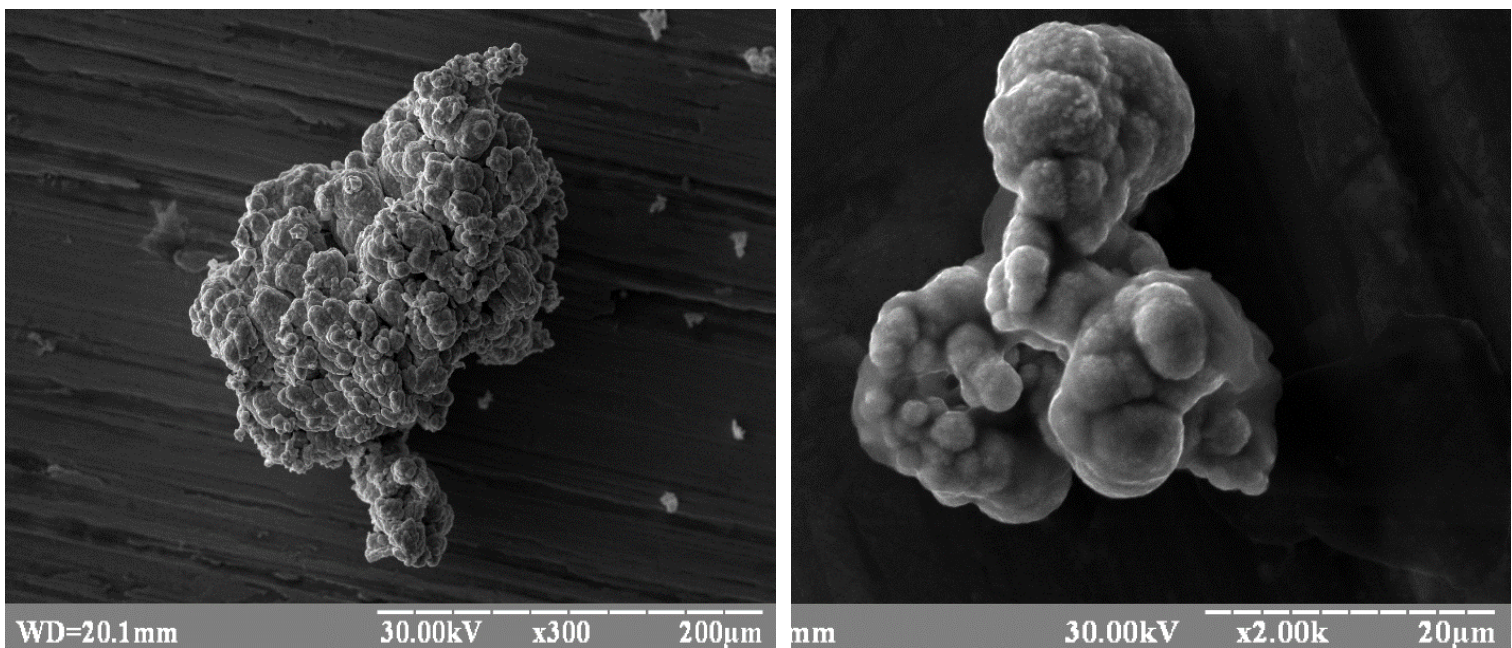

Fig. 3. Morphology of Cu-graphite particles from electrolyte containing PA $4000(0.025 \mathrm{~g} / \mathrm{l})$
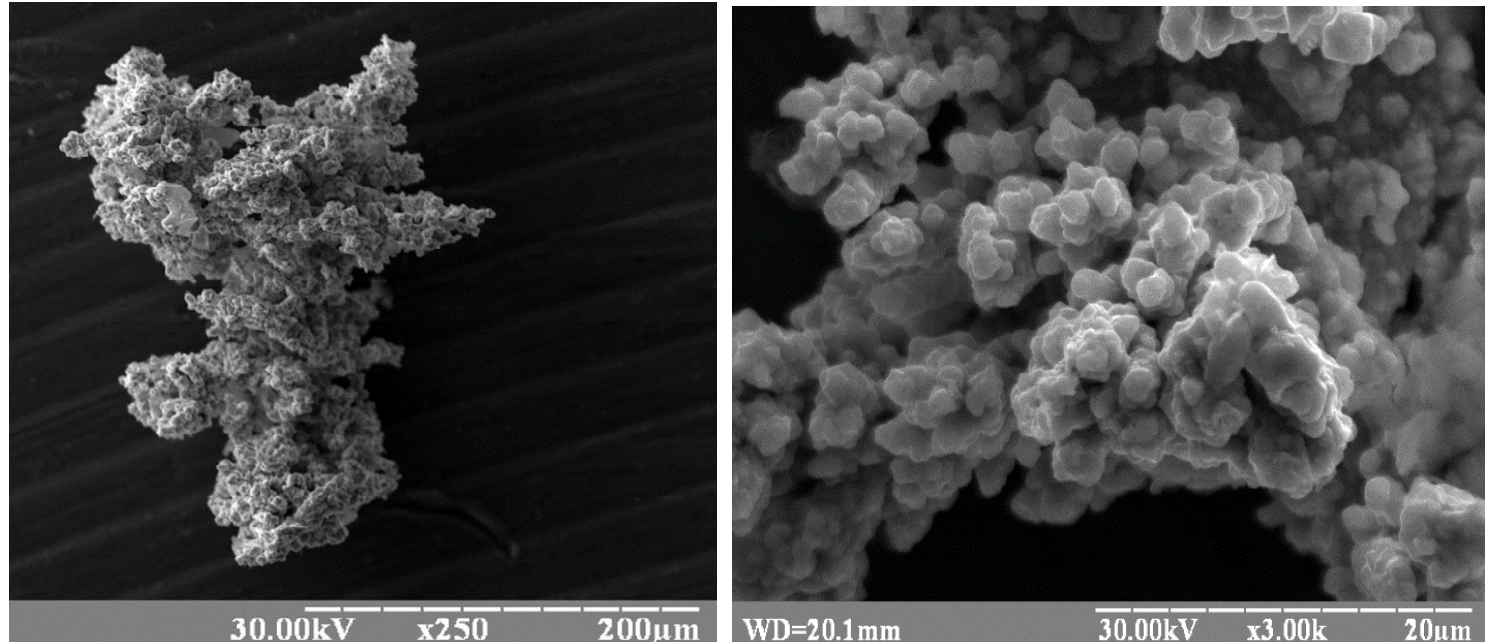

Fig. 4. Morphology of Cu-graphite particles from electrolyte containing SDS (0.5 g/l) 


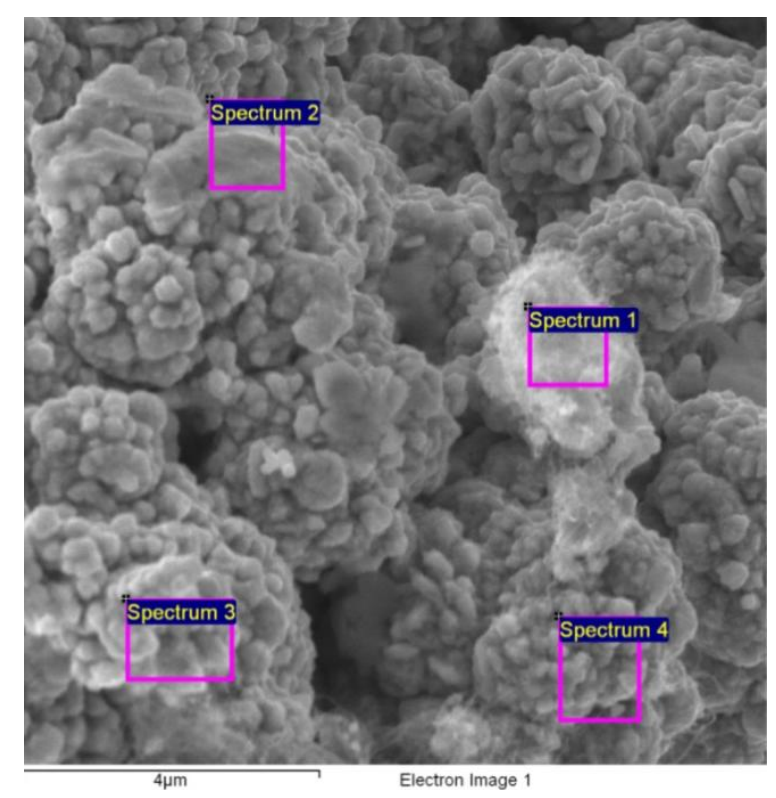

Elemental composition (wt \%) of $\mathrm{Cu}-\mathrm{CNT}$ powder in the points shown in Fig. 5

\begin{tabular}{|c|c|c|c|}
\hline Spectra & $\mathrm{C}$ & $\mathrm{O}$ & $\mathrm{Cu}$ \\
\hline Spectrum 1 & 44.69 & 5.86 & 48.84 \\
\hline Spectrum 2 & 18.67 & 1.38 & 79.88 \\
\hline Spectrum 3 & 17.97 & 1.36 & 80.66 \\
\hline Spectrum 4 & 11.86 & 1.01 & 87.13 \\
\hline
\end{tabular}

Fig. 5. SEM image of Cu-CNT powder deposited from ultrasonically agitated solution with CTAB surfactant

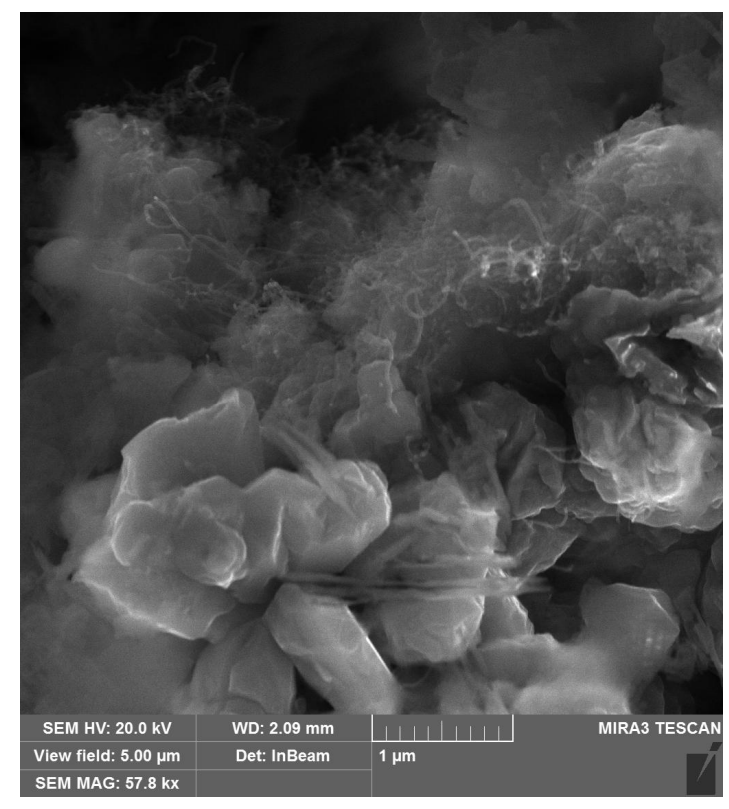

a)

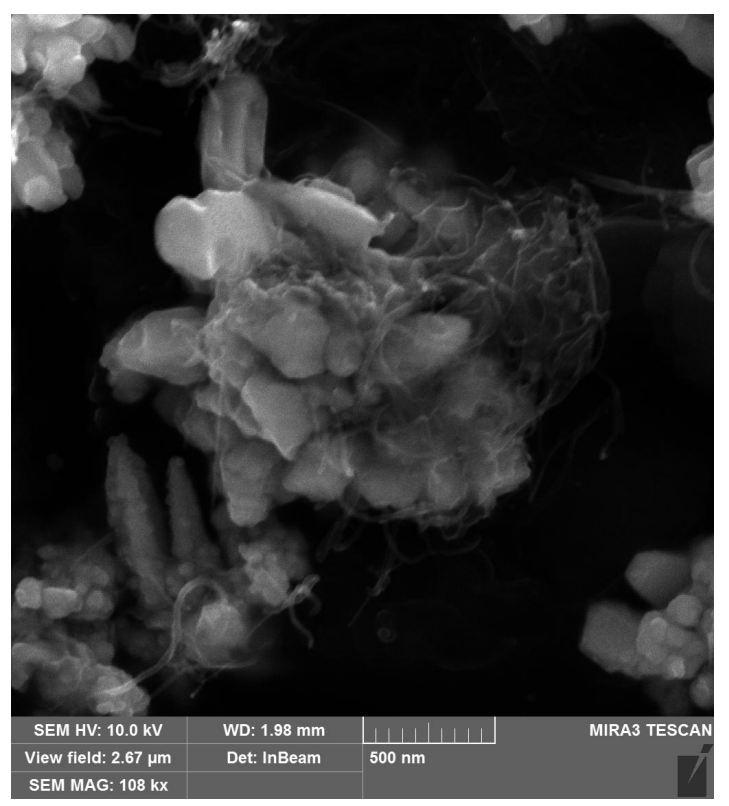

b)

Fig. 6. SEM images of Cu-CNT powder without (a) and with (b) ultrasonic agitation

In order to separate the CNTs agglomeration the solution with surfactant CTAB and CNTs $(0.18 \mathrm{~g} / \mathrm{l})$ was treated by ultrasound for $30 \mathrm{~min}$. The vibration frequency of the ultrasonic mixer was $14.1 \mathrm{kHz}$. Figs. 5 and 6 show the SEM images of deposited $\mathrm{Cu}-\mathrm{CNT}$ powder surface.

According to the local microanalysis the concentration of CNTs in particles varies from 11 to 44 wt $\%$, which gives us evidence that we have succeeded to produce composite powder with high content of $\mathrm{CNTs}$. The analysis of the $\mathrm{Cu}-\mathrm{CNT}$ powders morphology and their elemental composition have shown that when the electrolyte with CNTs is agitated by ultrasonic, the forming powders are more dispersed and the embedded CNTs are more uniformly distributed.

The results have shown that surfactant CTAB contributes to the co-deposition of copper and carbon component (graphite, CNT). We can assume that the molecules of cationic surfactant CTAB dissociate in the aqueous solution and form the cation with a long hydrophobic chain (hydrophobic tail). Both graphite and 
carbon nanotubes being the non-polar hydrophobic substances well adsorb the surfactants from polar fluids, such as aqueous solutions. It can be assumed that the hydrophobic non-polar part of the CTAB adsorbs on the surface of carbon material (graphite, CNT) (Fig. 7). Due to this the stabilization of the disperse system occurs.

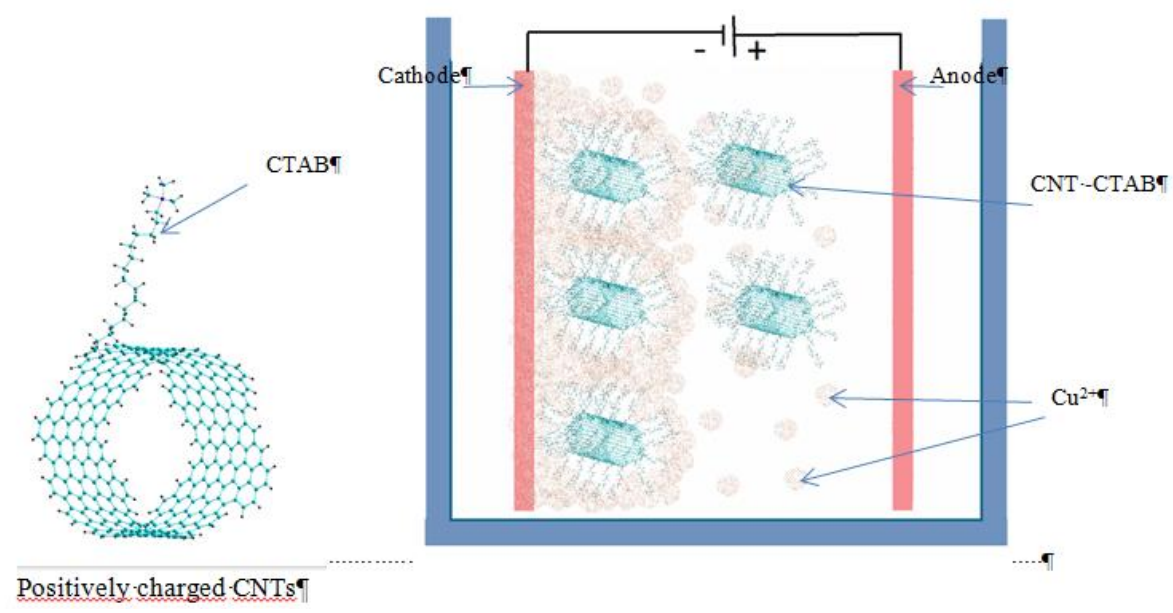

Fig. 7. Schematic diagram of electrodeposition of $\mathrm{Cu}-\mathrm{CNT}$ s composite with $\mathrm{CTAB}$

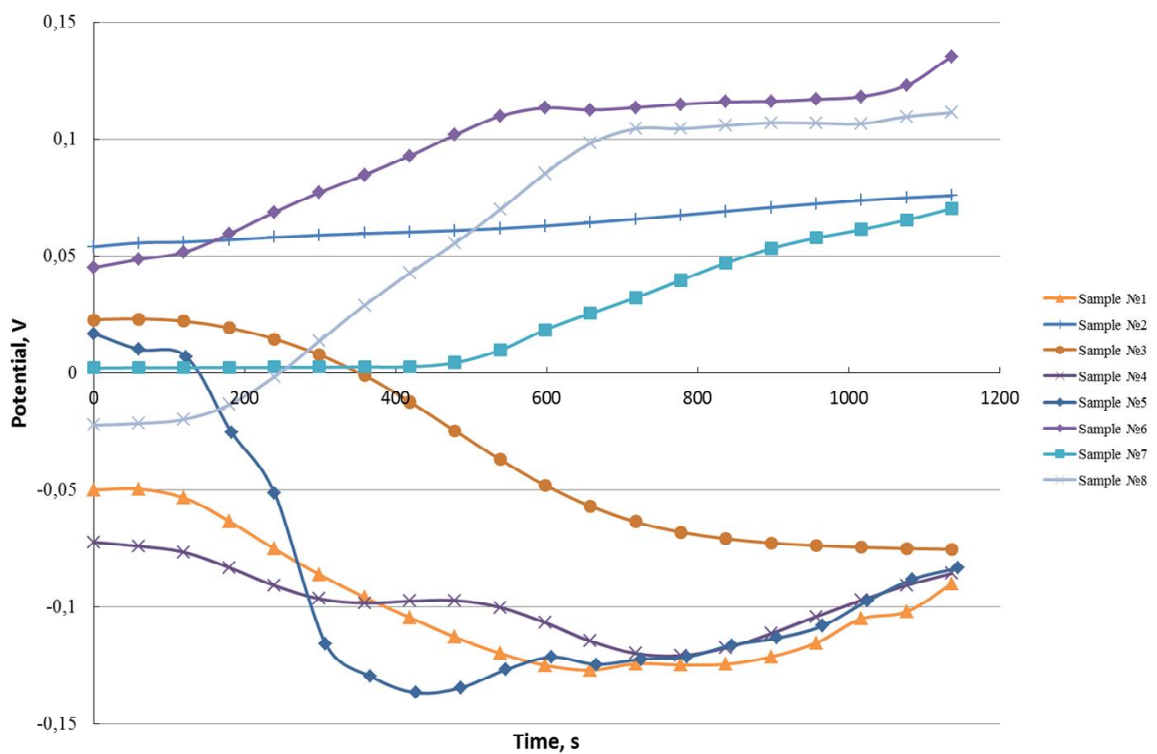

Fig. 8. Kinetic curves of steady state electrode potential of composite copper-carbon powders samples in $3 \% \mathrm{NaCl}$ solution

In order to determine relative stability of $\mathrm{Cu}-\mathrm{CNTs}$ composite powders obtained from different solutions, their corrosion resistance was tested for one month in a moist atmosphere. The powder was placed on a special porous surface in the humidity chamber, which created conditions for accelerated atmospheric tests.

All types of surfactants in the electrolyte contribute to increasing the powder surface corrosive protection when using the additional stabilization by $0.15 \%$ soap solution. However, only CNT additive to the electrolyte also protects against oxidation powder without sta- bilization. Research has shown that the powder obtained with the addition of carbon nanotubes and CTAB in an electrolyte has the best corrosive resistance as well.

Impact on the steady state electrode potential in the modeling solution, for example $3 \% \mathrm{NaCl}$, is important when studying the mechanism of surfactants action. Our results given in Fig. 8 have shown that the initial potential of copper powder is shifted to the negative side. In all samples of copper powders, which were deposited from solutions with surfactant $\mathrm{CTAB}$, we observed the increase of the potential, indicating the inhibition of oxidative reactions. 
At the same time, the potential of copper composite powder deposited from electrolyte with CNTs and surfactant $\mathrm{CTAB}$ was changed more rapidly, and we can conclude that such powder has good corrosion resistance and better stability than others.

Since the corrosion of metals is directly caused by ionization of the metal, the dependence of the potential on the stationary ionization rate is the most important characteristic of its resistance to environments and indirect evidence of their stability.

The more positive is this potential, the better is corrosion resistance of composite powder. On the basis of the experimental data, it can be concluded that a rapid increase in the potential of samples No. 2, 6, 7 and 8 has positive effect on their corrosion properties. Corrosion resistance of electrical contacts, for example sliding contact of city electric transport working in the air, is an important characteristic.

\section{Conclusions}

In this work, copper-graphite and copper-CNTs composite powders were obtained via electrodeposition.

The using of cationic surfactant $\mathrm{CTAB}$, in comparison with surfactants of another action, contributes to the co-deposition of graphite and copper. Deposited powders shape presented by branched dendrites of multiaceted form and particles size is most dispersed. The change in the concentration of surfactant did not significantly affect the shape and size of the powder particles.

$\mathrm{Cu}$-CNTs composite powders deposited with CTAB also consist of finer particles of the size up to $5 \mu \mathrm{m}$, and the embedded CNTs were more uniformly distributed when the electrolyte with CNTs and surfactant was agitated by ultrasonic.

Additives of CNTs and surfactant CTAB in the electrolyte increase the corrosion resistance of copper composite powder tested in the climatic chamber.

Electrochemical research has shown that the potential of $\mathrm{Cu}-\mathrm{CNTs}$ composite powder deposited from electrolyte with surfactant $\mathrm{CTAB}$ was changed more rapidly, and we can conclude that such powder has good corrosion resistance and is potentially the most stable one.

\section{Acknowledgments}

The authors thank Academician O.M. Ivasishin from G.V. Kurdyumov Institute for Metal Physics of the NAS of Ukraine for provided CNTs.

\section{References}

[1] Pavlenko V., Yas D.: J. Powder Metall. Met. Ceram., 1976, 15, 89. https://doi.org/10.1007/BF00793555

[2] Uk P-H., Chung T-J., Lee H.: J. Ceram. Process. Res., 2017, 18, 440.
[3] Chu Y., Yu G., Hu B. et al.: Adv. Powder Technol., 2014, 25, 477. https://doi.org/10.1016/j.apt.2013.07.003

[4] Chen L., Yu G., Chu Y. et al.: Adv. Powder Technol., 2013, 24,

281. https://doi.org/10.1016/j.apt.2012.07.003

[5] Ajayan P., Schadler L., Braun P. (Eds.): Nanocomposite Science and Technology. Wiley-VCH Verlag GmbH, Weinheim 2003. https://doi.org/10.1002/3527602127

[6] Toth G., Maklin J., Halonen N. et al.: Adv. Mater., 2009, 21, 2054. https://doi.org/10.1002/adma.200802200

[7] Berber S., Kwon Y., Tomanek D.: Phys. Rev. Lett., 2000, 84, 4613. https://doi.org/10.1103/PhysRevLett.84.4613

[8] Jayathilaka W., Chinnappan A., Ramakrishna S.: J. Mater. Chem., 2017, C5, 9209. https://doi.org/10.1039/C7TC02965A

[9] Jiang L., Gao L., Sun J.: J. Colloid Interf. Sci., 2003, 260, 89. https://doi.org/10.1016/S0021-9797(02)00176-5

[10] Moore V., Strano M., Haroz E. et al.: Nano Leters, 2003, 3, 1379. https://doi.org/10.1021/nl034524j

[11] Rastogi R., Kaushal R., Tripathi S. et al.: J. Colloid Interf. Sci., 2008, 328, 421. https://doi.org/10.1016/j.jcis.2008.09.015

「12] Strano M., Moore V., Miller M. et al.: J. Nanosci. Nanotechnol., 2003, 3, 81. https://doi.org/10.1166/jnn.2003.194

[13] Vaisman L., Wagner H., Marom G.: Adv. Colloid Interf. Sci., 2006, 128-130, 37. https://doi.org/10.1016/j.cis.2006.11.007

[14] Schneider M., Weiser M., Dorfler S. et al.: Surg. Eng., 2012, 28,

34. https://doi.org/10.1179/1743294411Y.0000000095

[15] Arai S., Saito T., Endo M.: J. Electrochem. Soc., 2010, 157,

D147. https://doi.org/10.1149/1.3280034

[16] Arai S., Suwa Y., Endo M.: J. Electrochem. Soc., 2011, 158,

D49. https://doi.org/10.1149/1.3518414

[17] Ning D., Zhang A., Wu H.: Materials (Basel), 2019, 12, E392. https://doi.org/10.3390/ma12030392

[18] An Z., Toda M., Ono T.: 2016 IEEE $29^{\text {th }}$ Int. Conf. on Micro Electro Mechanical Systems (MEMS). 24-28 Jan. 2016, Shanghai, China. https://doi.org/10.1109/MEMSYS.2016.7421678

[19] Guo H., Zhu H., Lin H., Zhang J.: Colloid Polym. Sci., 2008, 286, 587. https://doi.org/10.1007/ s00396-007-1828-0

[20] Zheng L., Sun J., Chen Q.: Micro Nano Lett., 2017,12, 722. https://doi.org/10.1049/mnl.2017.0317

[21] Arai S., Endo M.: Electrochem. Commun., 2003, 5, 797. https://doi.org/10.1016/j.elecom.2003.08.002

[22] Tihomirov V.: Peny. Teoriya i Praktika ih Polucheniya i Razrusheniya. Khimia, Moskva 1983.

Received: June 24, 2019 / Revised: September 26, 2019 / Accepted: December 22, 2019

\section{ДОСЛІДЖЕННЯ ВПЛИВУ ПОВЕРХНЕВО- АКТИВНИХ РЕЧОВИН НА ОДЕРЖАННЯ КОМПОЗИЦІЙНИХ ПОРОШКІВ МІДЬ-ВНТ}

\begin{abstract}
Анотація. В роботі експериментально визначено вплив поверхнево-активних речовин (ПАР) різного типу на прочеси сумісного електрохімічного осадження композиційного порошку мідь-вуглець (графіт, вуглещеві нанотрубки (ВНТ)). Показано, що введення ПАР СТАВ зменшує розмір частинок порошку та покрашує їх корозійну стійкість. Максимальний ефект одержано при введенні до електроліту ПАР катіонної дї - СТАВ 3 одночасним обробленням ультразвуком для диспергування ВНT.
\end{abstract}

Ключові слова: поверхнево-активна речовина, вуглечеві нанотрубки (ВНТ), мідний композиційний порошок, електроосадження, ультразвук, корозійні властивості. 